\title{
Terrorist Use of Smuggling Tunnels
}

\author{
Terrance G. Lichtenwald and Frank S. Perri
}

PMB 141, 6260 E. Riverside Blvd, Loves Park, IL 61111, USA

\begin{abstract}
This article examines terrorists' use of smuggling tunnels to finance terrorism and/or launch terrorist operations. Israel's Operation Pillar of Cloud and Hamas' Operation Stones of Shale are used to illustrate both the physical structure of smuggling tunnels and social networks of the people who build and use smuggling tunnels. The sociological factors of terrorists and criminals engaged in smuggling in the same country, such as the Gaza Strip and Egypt during peaceful times and the Gaza Strip and Israel during a state of war, is examined. The article proposes the application of open-source social-network models applicable to regional and transnational tunnel analysis during times of peace and war, employing intelligence from law enforcement and national security sources to improve border security.
\end{abstract}

Keywords: Smuggling, tunnels, terrorism, operation pillar of cloud, operation pillar of defense, operation stones of shale, operation shale stones.

\section{INTRODUCTION}

Each year, countries spend a significant portion of their national security budget on border security to curb illegal immigration, absolute and conditional contraband smuggling, human trafficking, and the threat of terrorists crossing their borders. Absolute contraband includes arms, munitions, and various materials such as chemicals and certain types of machinery, used directly to wage war or converted into instruments of war. Conditional contrabands are goods susceptible for both warlike and peaceful purposes and include items such as fuels and food. Law enforcement and national defense forces must draw on their resources to address national security problems presented by the flow of absolute contraband through above- and below-ground smuggling tunnels during times of peace and war, as well as during terrorist operations launched from tunnels. The ability to monitor not only the individuals and groups, but also the networking interactions between and among criminal and terrorist organizations that exploit smuggling tunnels, would be of great benefit to border security in diverse regions of the world: Canada and the United States, United States and Mexico, Egypt and the Gaza Strip, Israel and the Gaza Strip, and the Ukraine into the European Union ("Slovakia's Borders: Tunnel Vision," 2012).

In this article, the authors reviewed information gathered from three sources: (a) results from Israel's Operation Pillar of Cloud also known as Operation Pillar of Defense and Hamas' Operation Stones of Shale; also known as Stones of Baked Clay; (b) results

*Address correspondence to this author at PMB 141, 6260 E. Riverside Blvd. Loves Park, IL 61111, USA Fax: (815) 282-6457; E-mail: tgl3155@aol.com from media reports and government documents regarding terrorists' attacks using tunnels and the use of tunnels to finance terrorist operations; (c) peer review literature using social network analysis of smuggling and terrorist operations.

\section{OPERATION PILLAR OF CLOUD}

On November 14, 2012, Israel Defense Forces (IDF) and Hamas engaged in an eight-day battle staged in the Gaza Strip during which Israel launched a military attack targeting Hamas leadership, command and control centers, storage facilities including underground smuggling tunnels, and rocket launchers and launch sites that Israel judged to pose a threat to its national security. Israel called its action Operation Pillar of Cloud; Hamas called its campaign Operation Stones of Shale. Among 1,500 terrorist sites targeted, Israel attacked 30 senior Hamas and Islamic Jihad terrorists, 19 high level command centers, 980 underground rocket launchers, 42 operation rooms and bases owned by Hamas, 26 weapons manufacturing and storage facilities, and dozens of long-range rocket launchers and launch sites (Dayan, 2012; "Summary of Operation Pillar of Defense," 2012).

Israel reported it successfully targeted 140 of the estimated 500 smuggling tunnels in order to impair Hamas weapons smuggling capabilities and 66 tunnels used for terrorist operations ("Gaza Tunnels," 2012). Hamas estimates Israel bombed $60 \%$ of the tunnels; some were damaged and quickly repaired, and others were flattened. The authors surmise that Hamas' estimate of $60 \%$ targeting of tunnels suggests that, by Hamas estimates, 300 tunnels used for terrorist operations were correctly identified and successfully targeted, as opposed to Israel's total of 206 tunnels. 
Applied behavioral analysis of Israel's political and military behavior during the 2012 war provides several topics worthy of exploration. First, Operation Pillar of Cloud was in response to the consistent rocket attacks on Israel. Therefore, Israel was motivated to stop or reduce the rocket attacks. Second, Israel announced that it was aware of the estimated 500 smuggling tunnels. Given the available number (e.g., 500 possible tunnels and 140 targeted), the authors surmise that Israel's counterattack of targeting only 140 of the 500 possible targets means that $28 \%$ of the possible smuggling targets were hit. Third, Israel reported targeting only 66 of the 500 tunnels identified by Israel as being used for terrorist operations, which the authors surmise means that approximately $13 \%$ of the estimated 500 tunnels were used for terrorist operations.

The authors estimated $13 \%$ of tunnels used in launching terrorist operations and $28 \%$ used to support terrorism are reflective the relatively low percentage of the 500 covert tunnels that posed a direct threat to border security. The authors opine that for Israel to control the smuggling of absolute contraband, reduce the locations from which the attacks took place, and subdue the command and control structure of the belligerent groups, Israel would have to understand the social network of the people involved, as well as the location and structure of the terrorist smuggling tunnels among hundreds of smuggling tunnels not judged by Israel to pose a threat to its national security. The desire and ability to target only those individuals and tunnels that threaten national security is a distinction between terrorist and military operations.

Israel's analysis and successful selective targeting of both smuggling tunnels and social networks of criminals and terrorists involved in smuggling tunnels displayed during Operation Pillar of Cloud (ability to hit $13 \%$ and $28 \%$ of specific tunnel structures and target specific individuals) was the result of significant changes in Israel military doctrine outlined in the Winograd Committee report following the Second Lebanon War in 2006.

The Second Lebanon War began following Israel's military response when, after four prior failed attempts, Hezbollah succeeded in abducting two IDF soldiers, Eldad Regev and Ehud Goldwasser, during a crossborder terrorist raid launched from a tunnel and exfiltrated back to Lebanese territory (Blanford, 2006 as cited in Farquhar, 2011, pp.60-61; Exum, 2006; Ilan \& Haaretz Correspondent, 2008).
Germaine to the issue of what a terrorist attack on a border patrol station may look like was that the Second Lebanon War began on "July 12, 2006, when Hezbollah terrorist organization attacked two Israeli Defense Forces armored Hummer jeeps patrolling along the border with gunfire and explosives, in the midst of massive shelling attacks on Israel's north. Three soldiers were killed in the attack and two were taken hostage. Later that day, four IDF soldiers were killed when their tank hit a mine some six kilometers inside Lebanese territory" (Cohn-Almagor \& HalevaAmir, 2008, p. 27). In respect to border security intelligence, the exact spot where the two IDF soldiers were abducted was the exact location where Hezbollah planed to carry out another raid in May 2006. However, IDF intelligence learned of Hezbollah's plans, and in response IDF openly deployed a large force in an effort to deter any possible attack (Schiff, 2006). Also of interest to agencies tasked with border security is that the specific site of the abduction was an area of the border just south of Ayta ash Shab along the Lebanese border from Rosh HaNigra to Shebaa with the unique feature that an Israeli position laid just down the road and up a hill. Hezbollah identified the "blind spot" near Ayta ash Shab, and conducted through reconnaissance and had "Task Organized" the abduction operation to include a support element, an assault element, and a breach team (Exum, 2006, p. 8).

Israel's Prime Minister Ehud Olmert stated, "The unequivocal opinion of the (Israel) defense establishment before the Second Lebanon War was that in the case of an abduction attempt or rocket attacks, Israel must respond harshly in the entire area in a disproportionate fashion," in order to deal with the Hezbollah threat" (Ilan, 2008, para. 2).

An in-depth military analysis of the Second Lebanon War in 2006 and the Operation Cast Lead is beyond the goal of this paper and is addressed elsewhere. (Katz \& Hendel, 2013; Farquhar, 2011; Exum, 2006) However, it was the Winograd Commission's report that in part addressed Israel's policy regarding abduction of Israelis by terrorists and was reflected in Operation Pillar of Cloud that is of interest (Farquhar, 2011). In sum, the Winograd Commission report indicated that Israel invaded Lebanon after a surprise rocket attack by Hezbollah. The Second Lebanon War left the Israeli people deeply troubled and their confidence in their defense forces shaken. Following the Winograd Commission's report, Israel's motivation in future combat operations has been to go after the tunnels as a designated center of gravity essential to 
Hamas (and Hezbollah) operations. It would be the equivalent of attacking a logistics supply line such as the German U-boat campaign against Allied shipping or Sherman's total war policy during the Civil War where he targeted Confederate railway supply lines (among other targets).

Although the United States has not had a soldier abducted on either of its land borders, in February 1985 the United States was confronted with the abduction, torture, and murder of United States Drug Enforcement Administration (DEA) Agent Enrique "Kiki" Camarena while he was on assignment in Mexico. The murder of Agent Camarena resulted in the United States government via the DEA launching Operation Camarena, which entailed stopping and searching every vehicle coming from Mexico, turning the border into a 2,000-mile nightmare. (Russell, 2001) Agent Camarena and his pilot Alfredo Zavala Avelar, who assisted him, were abducted following a significant drug interdiction at a 1,000-hectare marijuana plantation orchestrated by Agent Camarena, which resulted in a huge loss for the drug trafficking organization (Beittel, 2013; Startex, 2011; Grillo, 2009). After the DEA received an audio tape of the interrogation and torture of Agent Camarena, which was motivated by the drug trafficking organization's attempts to find the leak in their organization which lead to the drug interdiction and murder of Agent Camarena, the DEA launched a murder investigation called Operation Leyenda.

Operation Leyenda was complex, and it involved issues of corrupt political and law enforcement officials in Mexico and the United States, as well as Mexican issues of extradition treaties and conflicting goals of law enforcement and intelligence agencies in both the United States and Mexico.Thus, the abduction, torture, and murder of a American law enforcement agent by a Mexican-based drug organization was addressed by a United States law enforcement response that was adjudicated in the United States criminal justice system.

Although Mexican-based drug organizations of the mid 1980s had a toxic effect on Mexican law enforcement and oversight, the nature of the United States-Mexico relationship provided an opportunity for a law enforcement-based response rather than a military response. The authors acknowledge that in the mid-1980s Miguel Ángel Félix Gallardo divided his drug organization into plazas or territories and criminal fiefdoms that controlled specific plazas (i.e., Sonora,
Gulf and Sinaloa Cartel as well as the Tijuana organization etc.)-all of which since the mid-1980s have gone through a process of division and developed into transnational crime organizations that employ terrorist tactics (Beittel, 2013, p.10). What remains unknown is the United States' response to a crossborder terrorist absolute contraband smuggling or terrorist-launched operations within the context of United States and Mexico agreements such as the Brownsville Agreement ("Attorney General Reno and Madrazo Sign Letter," 1998; Kempster, 1998). As of April 2013, Mexico ended its open relationship with U.S. security agencies that developed in recent years to fight organized crime and drug trafficking. U.S. law enforcement will now go through the federal Interior Ministry, the agency that controls security and domestic policy ("Mexico: Open Access to U.S. Agencies Ends", 2013).

Terrorist use of smuggling tunnels to both smuggle absolute contraband and launch terrorist operations has occurred on the borders of Israel and the Gaza Strip and between Egypt and the Gaza Strip. The Winograd report indicated that the military response in the Second Lebanon War was not based on a detailed, comprehensive and authorized military plan, nor based on careful study of the complex characteristics of the Lebanon area, but rather on a policy of immediate response to a terrorist abduction of IDF soldiers or Israel citizens (Cohen-Almagor \& Haleva-Amir, 2008, p. 32)

The Winograd report serves as a reference for countries that must evaluate the national security threat that smuggling tunnels pose to their border control officers, military personnel, and citizens, as well as the options available in the event that terrorists launch a terrorist attack, kill border guards, or abduct citizens or government employees.

Operation Pillar of Cloud began with the targeted killing of Hamas leader Ahmed al-Jabari (also known as Abu Mohammad) on November 14, 2012. Ahmed alJabari was well-known among his other activities as the individual who took responsibility for kidnapping IDF soldier Gilad Shalit in June 2006 by using a tunnel as part of the terrorist operation to kill or kidnap IDF soldiers. Of the 30 senior Hamas operatives targeted during Operation Pillar of Cloud, number five on the list (Table 1 below) published by IDF was Osama Kadi, senior operative in the smuggling operations in the southern Gaza Strip ("Summary of Operation Pillar of Defense," 2012). 
Table 1: Senior Operatives Targeted ${ }^{*}$

\begin{tabular}{|c|c|}
\hline Number / Name & Role \\
\hline \hline 1/ Ahmed Sai'd Halil Jabri & head of Hamas' military wing \\
\hline 2/ Hab's Hassan Us Msamch & senior operative in Hamas' police \\
\hline 3/ Ahmed Abu Jalal & commander of the military wing in Al-Muazi \\
\hline 4/ Khaled Shayer & senior operative in the antitank operations \\
\hline 5/ Osama Kadi & senior operative in the smuggling operations in the southern Gaza Strip \\
\hline 6/ Muhammad Kalb & Islamic Jihad senior operative in propaganda in Gaza city \\
\hline 7/ Ramz Harb &
\end{tabular}

*(Summary of Operation Pillar of Defense, 2012).

As demonstrated during the public killing of individuals accused of being spies who assisted Israel in the identification of targets during Operation Pillar of Cloud, it was probable that Israel had been gathering human intelligence on terrorist smuggling tunnels and networks for years prior to the 2012 war (Rudoren \& Akram, 2012; "Hamas Gunmen Execute Six," 2012; Kalman, 2012). The methods and sources of Israel human intelligence is not available in open sources; however, it is clear from Table $\mathbf{1}$ that Israel had analyzed the social structure of Hamas leadership and the individuals responsible for smuggling tunnels involved in absolute smuggling and launching terrorist operations from a tunnel.

The effectiveness of a military response to reduce the use of absolute smuggling tunnels and tunnels that support terrorist operations that threaten national security has been discussed in media and government documents that are now open source. For example, there were reports that dozens of tunnels targeted during Operation Pillar of Cloud remained out of commission, but they were quickly rebuilt ("Gazans Move Quickly to Rebuild Bombed Tunnels," 2012). The Israeli army acknowledged that smuggling had resumed, though it would not say whether the smuggling included new weapons. Gaza tunnel operators reported that there were tunnels reserved exclusively for Hamas shipments, presumably weapons (“Gaza Tunnels Being Quickly Rebuilt," 2012).

The issue of assessing smuggling tunnels that do and do not pose a threat to national security and hybrid tunnels that shift in respect to national security threat had been presented by these authors prior to Operation Pillar of Cloud (Lichtenwald \& Perri, 2011). The strength and weakness of using military intervention to reduce rockets being fired into Israel and absolute smuggling via tunnels was illustrated following Israel's 2009 Operation Cast Lead, which began on December 27, 2008, and ended on January 18, 2009. Operation Cast Lead was referenced in this article because the mission objectives of Operation Cast Lead were similar to Operation Pillar of Cloud with Israel's stated goal of Operation Cast Lead to stop rocket fire into Israel and weapon smuggling into the Gaza Strip ("Israeli-Hamas Violence since Truce Ended," 2009; Bright, 2009; McCarthy, 2009 as cited in "The Gaza War," 2013).

In a cable written following Israel's 2009 Operation Cast Lead sent by the United States Embassy in Tel Aviv, Israel's expectations of what could and could not be gained from military operations targeting smuggling of absolute contraband tunnels and rocket-launch sites were expressed (U.S. Embassy Tel Aviv 2009a, para. 1). The cable stated in part: "In an office call with a visiting U.S. senior official, IDF Deputy Chief of Staff MG Dan Harel said that he appreciated the role of the U.S. in leading the recent effort in Copenhagen to address the Gaza smuggling problem with the international community, and reminded all that smuggling into Gaza has been a long-standing issue." $\mathrm{He}$ also stated that while Israel conducted over 500 air sorties over the tunnel complexes along the Philadelphia corridor during Operation Cast Lead, they (Israel) were not so naive as to think that the tunnels were all destroyed, and indicated that since the ceasefire, up to 100 tunnels have been rebuilt. Harel pointed out that the focus on Gaza was part of a bigger campaign to address the main issue of Iranian support to Hamas, along with Tehran's aid to smuggling and terrorist operations across the region (para. 3).

The sociological significance of the willingness and ability to continue to launch rockets into Israel following Operation Pillar of Cloud was underscored during President Obama's first visit to Israel when two rockets 
were launched from the Gaza Strip and landed in Israel on March 21, 2013 ("Two Rockets Fired from Gaza Strip," 2013). Additional rocket attacks targeting Israel occurred during the time this article was being researched and undergoing peer review. Of interest to agencies responsible for cross-border security is that the rocket attacks and terrorist abduction operations, although carried out by Hezbollah and Hamas, are sponsored by Iran, a country that does not share a border with Israel. Iran's history of exporting terror to Israel and Western democracies is what made the cross-border attacks and terrorist smuggling operations of interest to border security agencies outside the Middle East.

Although military operations such as Operation Pillar of Cloud and Operation Cast Lead have taken place-with mission goals of reducing or stopping rocket attacks on Israel and destroying or disrupting absolute contraband smuggling from tunnels to support the rocket attacks and terrorist operations-the social networks of the criminal and terrorist organizations remain resilient. Thus, the authors call for additional analysis of the networks and geopolitical dynamics of the region where smuggling tunnels are used for absolute contraband smuggling and terrorist operations.

\section{CRIMINAL AND TERRORISTS SOCIAL NETWORK ANALYSIS}

The amount of money made by Hamas off taxing contraband smuggled through Gaza Strip tunnels, as well as the political advantage of Hamas controlling both absolute and conditional contraband tunnel smuggling, has been addressed in the business management popular press. For example, one source reported that "the tunnels generate $\$ 188$ million in tax revenues on things like cigarettes, gas and building materials" (Topol, 2013, para. 13).

Palestinians estimate that $25 \%$ of the Hamas government's budget comes from taxes imposed on the owners of the underground tunnels. For example, Hamas has imposed a $25 \%$ tax and a $\$ 2,000$ fee on every car that is smuggled into the Gaza Strip. Hamas also charges $\$ 15$ for each ton of cement, eight cents for a pack of cigarettes, and 50 cents for each liter of fuel smuggled through the tunnels (Toameh, 2012).

The political advantage the smuggling tunnels provided to Hamas included that while the tunnels are essential for transporting absolute contraband and materials into Gaza, they are also critical for maintaining the goodwill of Gazans by providing them with cut-price commodities even with surcharges added by Hamas officials (Alster, 2013). The financial rewards of engaging in criminal smuggling of contraband between Egypt and the Gaza Strip are an important part of transnational tunnel analysis because the Gaza Strip is a site of an estimated 600 millionaires (Toameh, 2012).

These authors opined that a propaganda advantage for Hamas is that attacks on Gaza Strip tunnels can be propagandized as an unreasonable response by Israel to control conditional as opposed to absolute contraband or the launching of terrorist operations from the tunnels. Thus, tunnels provided financial support to Hamas, a "cover for action" in respect to Hamas smuggling absolute as opposed to conditional contraband, and justification for portraying Israel military operations as unreasonable.

In addition to structural analysis of smuggling tunnels, the critical need for analysis of social networks in which criminal and terrorist individuals, cliques, and groups have linked together was underscored in the study of secret cables from the United States Embassy in Tel Aviv. This study indicated that absolute contraband has been specifically designed to facilitate smuggling through Gaza Strip tunnels. Therefore, a criminal investigation of the structure of any specific tunnel would not necessarily give the appearance to law enforcement that a tunnel had been designed for or had been used to smuggle absolute as opposed to conditional contraband.

\section{MORE SOPHISTICATED IRANIAN WEAPONS TO HAMAS}

In response to a query on the sophistication of Hamas weapons, Maj. Gen. Dan Harel stated that Hamas had Chinese- and Iranian-made $122 \mathrm{~mm}$ rockets with a range of 30 kilometers. The authors infer from this reference that Harel was speaking about the $122 \mathrm{~mm}$ Grad rockets that are normally launched from the Russian BM-21 MLRS the Iranian version of the $122 \mathrm{~mm}$ was designed specifically for Hamas, as it came in four pieces that could fit through narrow tunnels and be reassembled in Gaza. Harel also stated that sophisticated antitank guided missiles (ATGMs) were found in Gaza, including the Russian-made Konkours system. Hamas also had SA-7 surface-to-air missiles and sophisticated improvised explosive devices of all varieties. Lastly, Harel said that Israel has 
sensitive intelligence that Iran was constructing an additional Hamas-specific missile, based on the Fajr, which will have a range beyond 40 kilometers ("IDF Deputy Chief Of Staff," 2009, para. 5).

Exum (2006) notes that Hezbollah effectively used a variety of weapons systems, ranging from AK-47, M16 , or $M-4$ carbines, to short and medium range rockets, anti-tank missiles and C-802 anti-shipping missile during the 2006 war (see Table 2). Iran-based terrorist organizations (i.e. Hezbollah, Hamas, etc.) involved in cross-border operations have access to military grade weapons that outstrip law enforcement.
The modification of absolute contraband so that it can be smuggled through tunnels indicates that transnational tunnel analysis must include social network analysis in addition to structural analysis of tunnels. Therefore, transnational tunnel analysis is at the crossroads of social network analysis of criminal groups, smugglers, terrorist organizations, and terrorist cells. Tunnels that originate from a clandestine location (hidden room in a house) to a position under a border checkpoint or military facility are considered to have a higher probability of launching terrorist operations than conditional smuggling tunnels. In this paper, the authors are addressing smuggling groups and tunnels.

Table 2: Weaponry Used by Hizballah during the July War 2006

\begin{tabular}{|c|c|c|c|c|}
\hline Type & Name & $\begin{array}{c}\text { Caliber } \\
\text { (Millimeters) }\end{array}$ & $\begin{array}{l}\text { Maximum Range } \\
\text { (Kilometers) }\end{array}$ & Comments \\
\hline $\begin{array}{l}\text { Surface to surface } \\
\text { rockets; short range } \\
(0-25 \mathrm{~km})\end{array}$ & Katyusha & 122 & 20 & $\begin{array}{l}\text { Exum (2006) provided no } \\
\text { comments in this section }\end{array}$ \\
\hline \multirow{4}{*}{$\begin{array}{l}\text { Surface-to-surface } \\
\text { rockets; mid to long } \\
\text { range }(>25 \mathrm{~km})\end{array}$} & $\begin{array}{c}\text { "Extended range" } \\
\text { katyusha }\end{array}$ & 122 & 35 & $\begin{array}{c}\text { New version of standard } \\
\text { katyusha }\end{array}$ \\
\hline & Fajr-3 & 240 & 43 & $\begin{array}{c}12 \text { barrels, truck-mounted } \\
\text { launcher }\end{array}$ \\
\hline & Uragan & 220 & 70 & Syrian-made \\
\hline & Fajr-5 & 333 & 75 & $\begin{array}{l}4 \text { barrels, truck-mounted } \\
\text { launcher }\end{array}$ \\
\hline \multirow[t]{2}{*}{ Shore-to-ship missiles } & C-701 & & 15 & Television guidance \\
\hline & C-802 Noor & & 120 & Onboard active homing \\
\hline $\begin{array}{l}\text { Unmanned aerial } \\
\text { vehicles }\end{array}$ & Mirsad-1 & & & $\begin{array}{l}\text { Hezbollah version of } \\
\text { Iranian Mohajer-4; three flown } \\
\text { during conflict }\end{array}$ \\
\hline \multirow[t]{3}{*}{ Antitank missiles } & RPG-29 & 105 & 0.5 & $\begin{array}{l}\text { Shoulder-fired, tandem } \\
\text { warhead }\end{array}$ \\
\hline & AT-13 Metis-M & 130 & 2 & Tandem warhead \\
\hline & AT-14 Kornet-E & & 5 & SACLOS guidance \\
\hline
\end{tabular}

Sources: Yiftah Shapir, "Artillery Rockets: Should Means of Interception Be Developed?" Strategic Assessment 9 , no. 2 (Autumn 2006), Jaffee Center for Strategic Studies, Tel Aviv University; Noam Ophir, "Look Not to the Skies: The IAF vs. Surface-to-Surface Rocket Launchers," Strategic Assessment 9, no. 3 (November 2006), Jaffee Center for Strategic Studies, Tel Aviv University; Amir Kulick, "Hizbollah vs. the IDF: The Operational Dimension," Strategic Assessment 9, no. 3 (November 2006), Jaffee Center for Strategic Studies, Tel Aviv University; Nicholas Blanford, "Deconstructing Hizbullah's Surprise Military Prowess," Jane's Intelligence Review, October 24, 2006;: GlobalSecurity.org; Federation of American Scientists Military Analysis Network. 
Katz and Hendel (2013, p. 28) provided a discussion of terrorist bunkers.

Papachristos (2011) noted that the distinction between the research published in sociology journals as opposed to criminology publications was that throughout the 1990s, the application of social network analysis to the study of criminology remained virtually flat with the exception of a few peaks (caused by one or two authors) and a slight uptick since 2005 (caused by the same one or two authors) (p. 102). In his review of social network models and analysis in the field of criminology, Papachristos described how social network factors such as form and content (p. 108), use of descriptive techniques that distinguish between criminal and noncriminal networks (pp. 110, 112), density and degree (p. 115), network centrality, involvement, selection, and composition (p. 118)specifically in relation to how analysis can be applied to the study of transnational criminal social networks-are critical tools for the study of criminology. He described in detail "two specific models, exponential random graph models, and dynamic actor-based models that could be powerful tools" (p.113). Papachristos advised that "networks—be they in neighborhoods, countries, or other large social systems-have multiple meaning and operate at multiple levels. It is the analyst's job to decide on the unit of analysis without excluding the possibilities that networks can operate at levels not necessarily measured in any given study" (p.129). Coles (2001) also noticed the neglect of social network analysis in the study of criminology during the 1990s. Carrington, Scott and Wasseman (2005) published a review of the specific methodologies for advanced social network analysis. In 2006, Ressler published a review of the history of social network analysis concepts and methodology and their application for intelligence gathering purposes. Ressler's review is important because it makes note of the two social network analysis methods-village survey, which dates back to the 1960s, and traffic analysis, which dates back to the 1980s. The village survey method was used to understand family and community relationships using open-ended interviews. One study using this method mapped out the clandestine structure of local and regional Communist organizations and associated "sympathetic" groups in Thailand (Ressler, 2006, p. 6).

The need for a reference manual on the methodology for conducting social network analysis of criminals and criminal groups was completed (Morsell, 2009). In 2010, McGloin and Kirk offered an overview of social network analysis and possible use in criminology, including new methodologies.

Of interest in this paper is that only one article was found regarding a social network analysis of individuals involved in illicit drug production (Mam, Kinney \& Pollard, 2008). However, recently, the social network of smugglers was researched by Olapegda \& Idemudia (2012). Their study applied the Developmental Smuggling Model (Lichtenwald, 2003; 2004). The Developmental Smuggling Model is a unified model that describes phases of smugglers and organizations. Smugglers are reported to fall within one of three different phases. Phase I smugglers are usually smuggling contraband to meet their own needs although they might smuggle enough to cover their expenses by selling some of the contraband. Phase II smugglers are divided into two subtypes of individuals. Subtype 1 is a group of individuals who know each other and have a shared value system. The members of Subtype 1 often refer to each other as friends. Subtype 2 individuals belong to a group who have a shared value system but may not know each other as well. Subtype 2 may be a subgroup of coworkers or members of a group such as a gang. Phase III smugglers and organizations are formed for the sole purpose of smuggling. The Phase III individual or business smuggles with sophistication. In general, the individuals in Phase III are raised in an environment where smuggling is encouraged and considered an acceptable behavior. The Phase III smuggling corporation is divided into formal departments such as counter intelligence, bribes, money laundering, and others. Olapegda \& Idemudia completed an analysis of Phase I smugglers and smuggling organizations in border areas in Nigeria. This nation shares land borders with Cameroon, Benin Republic, Republic of Togo, Chad and a marine border with Equatorial Guinea. Olapegda and Idemudia reported that "in a bid to stem the tide of smuggling, successive governments in Nigeria have put up a number of measures and legislation in addition to empowering the Nigeria Custom Service, yet the phenomenon has continued unabated" (p.59).

Oladeji reported (Oladeji, K., 2010 as cited in Olapegda \& Idemudia, 2012), "the Nigerian economy has suffered over the years; which has largely been attributed to a number of factors ranging from unarticulated economic policies, policy inconsistency, corruption, unstable political environment as well as external political and economic influences" (p. 59). One other major problem that is plaguing Nigeria's economy 
is smuggling. It is robbing Nigeria of huge amounts of revenue that should be derived from import duty, and it has led to the flooding of markets with substandard, fake, and expired products. Research has shown that smuggling is one of the most common crimes across Nigerian borders, and it also runs across the West African subregion (Akano, 1986; Oladeji, K., 2010; Oladeji, M.O., 2010).

As a means of looking at the sociology behind the criminal smuggling activity in Nigeria, Olapegda and Idemudia (2012) investigated dispositional factors (openness to experience, agreeableness, neuroticism, conscientiousness, extraversion, locus of control, and risk-taking propensity), and contextual factors (economic factors, family influence and peer influence) predicting Phase I smuggling behavior (Lichtenwald 2003; 2004). Two hundred smugglers, selected using a snowball selection process from two selected border towns in Ogun State, Nigeria, were the subjects in the study. The snowball method used by Olapegda and Idemudia is very similar to the village survey method described by Ressler (2006). Olapegda and Idemudia (2012) reported four key findings. First, dispositional factors and contextual factors jointly predicted smuggling behavior significantly among suspected smugglers. Second, economic factors were found to be the highest predictor of smuggling behavior. Third, locus of control was found to predict smuggling behavior. Fourth, peer influence significantly predicted smuggling behavior. There appeared to be a consensus among the majority of the smugglers sampled that they were introduced into the business either directly by peers who recruited them or indirectly through the envied lifestyles of their peers involved in the business.

Olapegda and Idemudia's (2012) identification of multiple factors present when Phase I smugglers began their smuggling activities is consistent with the Developmental Smuggling Model. Their work, which is worthy of study, involves social network analysis of the individuals and groups they identified regarding how the network evolves over time (i.e., who continues to smuggle, who drops out, who links with a more advanced smuggling groups - Phase II or Phase III, etc.). Olapegda and Idemudia's work is similar to that of Snijders (2001) and Heisman and Snijders (2003). Of interest to law enforcement and the intelligence community would be a longitudinal study similar to the data collected on smugglers by Olapegda and Idemudia (2012) of which smugglers or smuggling groups link over time with terrorists or terrorist cells or organizations and how the link does and does not change the dynamics of the smugglers and smuggling groups (Snijders, 2001; Heisman \& Snijders, 2003).

Olapegda and Idemudia (2012) collected data on individuals and their cliques as they began engagement in the criminal enterprise of smuggling. Morselli, Giguere, and Petit (2006) published a social network analysis cross comparison that compared and contrasted individuals involved in the criminal drug conspiracy investigated in Canada. Thus, the individuals under study, as opposed to those studied by Olapegda and Idemudia, had already developed their smuggling sophistication and network links. The smugglers in the Morselli et al. study were investigated by law enforcement in Britain, Spain, Italy, Brazil, Paraguay, Columbia, and Canada when their interactions were analyzed by Morselli, et al. (p. 4). These authors compared their information about the social network of the smuggling enterprise against the social network analysis of the 911 hijackers. Specifically, Morselli et al. (2006) compared their smuggling network against the terrorist network analysis completed by Krebs (2001). They advised that the comparison analysis indicated that "though security is an obvious issue for all criminal networks, terrorist networks are particular in their ability to assure this condition to a maximum. Within the trade-off, efficiency is added to the secure network through the contribution of participants who operate beyond the action segment of the network" (p. 4). The findings from the Morselli et al. (2006) study raised the question as to what extent, if any, do terrorist operatives view the pre-existing smuggling network as participants who operate beyond the action segment of the terrorist network. They found time to task and avoidance of detection are factors that could well serve to distinguish a terrorist network, at least a terrorist cell with participants who would launch an operation from a criminal group involved in smuggling. For purposes of recent developments in specific areas of the world, such as the border between the United States and Mexico, the extent to which a criminal organization needs to avoid government confrontation is a factor that will need to be measured region by region. For example, there are criminal organizations that engage in military-style battles with each other and will engage the military forces of the government (e.g., Los Zetas of Mexico).

Among smugglers and smuggling organizations, distinctions have been made between those that engage in multiconsignment conditional contraband that pose economic and health threats to governments, 
and those that threaten national security due to smuggling absolute contraband (Lichtenwald, Perri, \& MacKenzie, 2009). The subgroup of multiconsignment contraband smugglers and smuggling groups that traffic in absolute contraband has been addressed (Shelley et al., 2005; Shelley, 2012). The exploitation through taxation by terrorist groups of smugglers and smuggling organizations smuggling conditional contraband, in addition to terrorist groups smuggling conditional contraband to fund terrorist activities, is understood (Perri, Lichtenwald, \& MacKenzie, 2009). Specific terrorist smuggling enterprises designed to raise revenue for terrorist operations have been discussed in law enforcement journals (Billingslea, 2004).

A specific example of conditional contraband smuggling within the United States with the proceeds supporting Hezbollah is provided in the case of Mohamad Youssef Hammoud. This case is important from a social network analysis perspective because Hammoud, along with two of his brothers and 22 others, were indicted in 2000 in U.S. District Court in the Western District of North Carolina ("Mohamad Youssef Hammoud Sentenced," 2011). Following the indictment process, Hammoud and one of his brothers, Chawki Hammoud, were tried before a federal jury in Charlotte, NC, on the charge of providing material support to a designated foreign terrorist organization, Hezbollah. U.S. Attorney for the Western District of North Carolina Anne M. Tompkins said,

Mohamad Hammoud was a student and member of Hezbollah as a youth in his home country and came to the United States on a Hezbollah-driven mission. He loyally accomplished his mission by creating a criminal enterprise which accumulated millions of dollars in profits, purchased businesses in the U.S., preached radical Muslim fundamentalism as he led a clandestine terrorist cell in Charlotte, raised funds for the cause, and saw that the funds were delivered to Hezbollah leadership in Lebanon. ("Mohamad Youssef Hammoud Sentenced," 2011, para. 7)

The social network of family members and friends was evident in the indictment in that he was born in Lebanon, came into the United States illegally in 1992 and lived here by virtue of three sham marriages to U.S. citizens until his arrest.
In respect to social network analysis of terrorist and terrorist groups, Sagemen (2004) presented his analysis derived from the biographical data of 172 participants with jihadist roots in Egypt. Sageman's sample pool excluded all non-Muslim terrorists, as well as Muslim terrorists involved in domestic insurgency and in urban warfare against their own government and did not include Muslims fighting for the "liberation" of Kashir or Chechnya (p. 62). In large part Sageman (2004) studied the terrorist networks and terrorists who attacked "the far enemy" defined as the West in general and the United States in particular. Attacks have also included Germany, France and Italy (p. 43).

Sageman (2004) included the detailed accounts of life within the Hamburg and Montreal cells that planned attacks on the United States. He opined that the tight bonds of family and friendship, paradoxically enhanced by the tenuous links between the cell groups, contributed to the jihad movement's flexibility and longevity. Of note is that although Sageman's systematic analysis highlights the crucial role the networks played in terrorist operations how terrorist organizations are structured, his position was that the level of commitment and choice to embrace violence were entirely up to each terrorist. He advised "random attacks, such as stopping terrorists arbitrarily at our borders, will not affect the network's structure. These actions may stop individual terrorists from coming and operating here, but they will leave the network largely undisturbed" (p.140). Sageman cautioned about arrest of suspected terrorists based on unwitting association (p. 67), and the danger of not recognizing the radicalization process among a group of unemployed men living on welfare or thievery identified from law enforcement monitoring of conversations in Canada ( $p$. 101 ), and again during police monitoring in Germany (p.106) and Italy (p.108). The police monitoring had identified individuals in a clique who were involved in terrorist operations and had demonstrated the "formation of a network of friendships that solidified and preceded formal induction into the terrorist organization (p.108). Sageman (2004) opined that "because of the network's ability to spontaneously grow and selforganize, attacks against the terrorist network's large hubs must be undertaken simultaneously to break up the network, and Sageman suggested law enforcement strategies to investigate the social network nodes and links as well as peripheral social acquaintances and family systems (pp. 177-178). He provided the example of the Abu Sayyaf Group who "fell from favor with bin Laden when it degenerated into a criminal group 
interested primarily in kidnapping for ransom (p. 44) and that "the 9/11 operation was also unique in that it was totally funded by al Queda, freeing the operators from having to raise money themselves through petty crime and allowing them to keep a low profile" (p. 51). Sageman reported that most of the unskilled terrorists in the Maghreb Arab cluster were involved in petty crime (false documents, traffic, thefts, and credit card fraud) to support the jihad (p. 78).

Qin, Xul, Hu, Sageman, and Chen (2005) employed several advanced network analysis techniques ranging from social network analysis to web structural mining using a Global Salafi (GSJ) Jihad network dataset consisting of 355 terrorists. Qin et al. found $65 \%$ of the links between terrorist leaders (members with incoming links) are personal links (acquaintances, friends, relatives, and family members), while only $38 \%$ of links between the leaders and the followers (members with no incoming links) are personal links. Qin et al. reported that the high percentage of personal relationships between the leaders forms the trustworthy "backbone" of the GSJ network and the low percentage of personal relationships between other members and the core members helps keep the network decentralized, covert, and less vulnerable.

Research completed by Qin et al. (2005) provided several points of interest to the development of transnational analysis of smuggling tunnels. First, their dataset consisted of terrorists taken from a pool of a large global terrorist network roughly divided into four clumps based on their geographical origins-central member, core Arab, Maghreb Arab, and Southeast Asian-which indicates the transnational nature of the sample pool. Second, the GSJ database offered several known successfully planned and launched large-scale attacks against civilians across different countries, each of which received an in-depth social network analysis. Specific attacks included the 9/11 attacks in the United States in 2001, the bombing in Bali in 2002, and the bombing in Morocco in 2003. At the time of the publication none of the terrorist groups studied by Qin et al. had used cross-border tunnels to either support terrorist activities or to lunch terrorist attacks. In contrast, Operation Pillar of Cloud began with the killing of Ahmed al-Jabari and Osama Kadi, who used cross-border smuggling tunnels in terrorist operations or to fund a terrorist organization in the Gaza Strip.

The authors opined that in a manner similar to Qin et al. (2005), it would be possible to complete a social network analysis of the group structures of those involved in the use of tunnels to fund terrorism and or terrorist operations. The goal would be identification of key members, such as Ahmed Al Jabari and Osama Kadi, targeted during Operation Pillar of Cloud. The question is whether applying the social network analysis model or a modification of the model employed by Qin et al. will separate criminal from terrorist use of tunnels in other cross border regions of the world.

At issue is whether the model employed by Qin et al. is applicable to terrorist use of tunnels in the Gaza Strip given that Sageman (2004) described the "struggle for the liberation of Palestine as a straightforward jihad rather than as an effort to establish a Salafi Islamist state (p. 62). Specifically, he clearly stated that his finding may not be applicable to the Gaza Strip social networks. "Indeed, many Palestinian terrorists have traditionally been secular rather than religious although religious fanaticism seems to be ascendant...Furthermore, the Palestinian struggle involves complex social, economic, and political grievances as well as the goal of "liberation" of a former Muslim land" (p. 62). Sageman concluded that he would not include Palestinians in his research (2004) because they "would muddy the more purely ideological water of the global Salafi jihad...l suspect that Palestinian terrorism is significantly different from the global Salafi jihad in terms of the people it attracts and their behavior" (p. 62). For purposes of transnational tunnel analysis, the social network analysis must address individuals, cliques and organizations that in part or whole engage in conditional and absolute smuggling or launching terrorist operations in other regions of the world. A reliable model for distinguishing social networks between common smuggling criminals and terrorists engaged in smuggling for profit or to stage a terrorist operation, especially the use of clandestine smuggling tunnels, would be an essential tool in border security.

Karthika and Bose (2011a) reviewed the developments in methodology of social network analysis with specific discussion regarding criminal and terrorist networks. They later expanded upon their methodology for analysis of social networks (covert node) by providing illustrations and graphs (Karthika \& Bose, 2011b).

\section{UNITED STATES OF AMERICA-MEXICO TUNNELS}

From Fiscal Year 1990 to Fiscal Year 2011, law enforcement authorities discovered 149 cross-border 
tunnels along the border between Mexico and the United States, 139 of which have been discovered since Fiscal Year 2001. There has been a dramatic increase in the number of cross-border tunnels discovered in Arizona and California since Fiscal Year 2006, with 40 tunnels discovered in California and 74 tunnels discovered in Arizona ("Border Tunnel Prevention Act of 2012," 2012). The findings from Congress also included that trafficking and smuggling organizations are intensifying their efforts to enter the United States through tunnels and other subterranean passages between Mexico and the United States, and border tunnels are most often used to transport narcotics from Mexico to the United States, but tunnels can also be used to transport people and other contraband. An analysis of the Mexico-United States and the Canada-United States tunnels was discussed previously by these authors (Lichtenwald \& Perri, 2011).

Of particular interest in completing an analysis of the extent to which Mexican smuggling tunnels into the United States do and do not threaten national security was the extent to which tunnel construction and operations themselves were a source of violence between warring criminal groups, each of which have transnational crime links. Stewart and Reed (2013) cited the following example: This dynamic (violence in Mexico) first became visible in the early 1990s when Joaquin "El Chapo" Guzman Loera and his Sinaloa Federation partners sent forces from Sinaloa state into Tijuana, Baja California state-controlled at the time by the Arellano Felix brothers-to buy stash houses and construct tunnels for moving drugs across the border. In response, the brothers tortured and killed Sinaloa operatives in Tijuana and even tried to assassinate El Chapo (para. 3).

According to the 2011 study conducted by the Joint Policy and Research Forum studying the Hybrid Threat Crime Terrorism and Insurgency in Mexico, social dynamics of the Mexico-United States tunnels are considered from three perspectives.

First, the forum found, "United States policy discussions based on perceived differences in motivation due to ideology versus desire for financial gain between criminal and terrorist organizations using tunnels into the United States may matter little, for practical purposes, where interests converge and intersect" (p. 13). A specific example of the convergence and intersection was presented between Mexico-based criminal and Middle East-based terrorist organizations occurred when Said Jaziri, the former imam of a Muslim congregation in Montreal, was hidden in a car driven by a San Diego-area man who was pulled over by U.S. Border Patrol agents near an Indian casino east of San Diego on Jan. 11, 2011. Jaziri had allegedly paid a Tijuana-based smuggling group $\$ 5,000$ to get him across the border near Tecate, saying he wanted to be taken to a safe place anywhere in the U.S. (Marosi, 2011). Of interest to these authors was whether a social network analysis of the individuals involved with the Tijuana-based smuggling group would demonstrate any telltale social network markers either at the acquaintance, friend, or family level (Qin et al., 2005, p. 294) indicating that smuggling networks' willingness and ability to assist an imam to illegally enter the United States.

Second, a crime, terrorism, and insurgency study found that the demonstration of terrorist operations conducted by criminal organizations based in Mexicowith the specific adoption of tactics, techniques, and procedures of terrorists by the criminal organizationsappear the same regardless of who is president of Mexico and what is the policy of the Mexican government ("The Hybrid Threat: Crime, Terrorism, and Insurgency in Mexico," 2011. p. 13). For example, Manssor Arbabsiar, identified by U.S. agents as a member of the Quds force (a special unit in Iran's Revolutionary Guard), was arrested for plotting to assassinate Adel Al-Jubeir, the Saudi Arabian ambassador to the United States. Arbabsiar was captured in a sting operation that culminated when he approached an undercover DEA informant posing as a Zeta cartel member, seeking his help in coordinating with a Mexican drug cartel to assassinate the ambassador ("United States of America v. Manssor Arbabsiar and Gholam Shakuri," n.d.).

Of particular interest was the social network analysis of the individuals involved in the Arbabsiar assassination mission. Again, the question would be whether the existence of specific behavior in the social networks can be identified, either prior to or during the failed execution of the mission, especially as related to contacting the Zeta criminal group in Mexico, known for their preference of behaving like terrorists involved in cross border smuggling. Of interest in respect to social network analysis is understanding the motivations for Arbabsiar to attempt to link with the Zeta criminal group as the group most willing and able to engage in an assignation of a Saudi Arabian Ambassador. Thus, a terrorist group based in Iran contacts a transnational criminal group involved in cross border smuggling in 
Mexico to assassinate a government official from Saudi Arabia stationed in the United States.

The authors opined that the Arbabsiar affair was a critical event that challenged the traditional academic belief that terrorist and smuggling organizations do not interact to target governments or government officials because the former is dedicated to overthrow of a government and the second is not (Killebrew, 2011, p. 44). It is precisely because Arbabsiar, a known terrorist, perceived similarity between Mexico-based criminal organizations involved in smuggling and those involved in terrorism that he approached what he thought was a member of the Zeta smuggling organization based in Mexico to carry out a political assassination that would benefit a terrorist organization (p. 44). Arbabsiar's behavior is precisely what the academics have been predicting would not happen. The findings from Qin et al. (2005) regarding the different types of links between terrorist leaders, as opposed to terrorist leaders and terrorist operatives, indicates that the initial connection between group $A$ (criminals) and group B (terrorist operatives) is a vulnerable period susceptible to law enforcement or intelligence interdiction.

The academic argument that group A (criminals) and group $B$ (terrorists) are exclusive because all members of group A seek profit and all members of group B seek government control is a fallacy argument. The Arbabsiar case demonstrates a real-world event in which a terrorist bridged across group $B$ to group $A$. The assumed benefit from bridging across groups was the assassination of a government official. Transnational tunnel analysis will require the study of the interactions between group $A$ and $B$ and hopefully identify the goals (i.e., assassination, money laundering etc.) that are associated with the bridging from group $A$ to group B and group B to group A. Transnational tunnel analysis can be used in the study of the socialnetwork links among individuals who construct the tunnels, the terrorist operative using the tunnel or a terrorist operation, and the terrorist organization and country, if any, sponsoring the terrorist operation (i.e., Iran).

Although there are a wide variety of individuals and groups who are involved in smuggling in different regions of the world (Lichtenwald 2003; 2004), as evidenced in Nigeria (Olapegda \& Idemudia, 2012), national security concerns focus on the individuals and groups that collaborate with or have dedicated themselves to terrorist principles (i.e., the $28 \%$ and
$13 \%$ identified and targeted during operation Pillar of Cloud). In respect to the criminal groups in Mexico, it has been reported that every one of the criminal organizations has significant overseas connections, and is (in fact) an international criminal network. Likewise, Iran and Hezbollah, which are operating in conjunction with narcotic traffickers in Bolivia, Peru and Ecuador, have demonstrated direct and attributable connections (Killebrew, 2011, p. 43). Pertinent to transnational tunnel analysis is the possibility that social network analysis can map out the links between the criminal groups based in Mexico and the terrorist operation nodes in other regions of the world that use tunnels to launch terrorist attacks.

A multitude of factors influence development of individuals and organizations that constituted smuggling organizations based in Mexico. Individuals and groups that meet Phase II and III classification (Lichtenwald 2003; 2004) currently engage in transnational crime with profit methods including kidnapping, extortion, human trafficking, and stealing oil from companies run by the Mexican government. Although crime groups engage in traditional crime activities such as cargo theft and pirating CDs and DVDs, it is the willingness of criminal organizations to engage in terrorist strategies and tactics in concert with the transnational relationships of the criminal individuals and groups that requires the social network analysis employed by the intelligence community for the law enforcement agencies responsible for border security. It is not unreasonable to consider that, in the chaos of the current environment in Mexico, terrorist organizations will capitalize on their ability to exploit the Mexican-based criminal groups.

An alternative theory is that one or more of the fractured transnational criminal groups in Mexico will align through a connection with a Leader, Gatekeeper or Outliner (Qin et al., 2005, p. 294) with a specific terrorist cell or terrorist organization to assist in one criminal organization's elimination of a rival criminal organization and then arrange for the rival to be identified as the criminal organization that assisted the terrorist operation. The creation of a centrifuge of misdirection in which terrorist acts committed by one criminal group are attributed to a rival criminal group is an art practiced among the Mexican-based criminal groups. The goals of disinformation campaigns vary among the various Mexican criminal groups, but the tactic is used to intimidate rivals and authorities, garner support from local residents, dissuade support for rivals 
or misdirect rivals and authorities ("Mexico Security Memo: Prevalent Propaganda," 2013).

The potential opportunity for a Mexican-based criminal organization to align with a terrorist organization interested in launching a terrorist operation using smuggling tunnels presented itself in June 2009 when a terrorist spoke of his desire to exploit the Mexican-United States tunnels for a terrorist operation. In June, 2009, U.S. counterterrorism officials authenticated a video by an al Qaeda recruiter threatening to smuggle a biological weapon into the United States via tunnels under the Mexico border. The video aired as a recruitment tool, making clear that al Qaeda is looking to exploit weaknesses in U.S. border security. The video shows Kuwaiti dissident Abdullah al-Nafisi telling a room full of supporters in Bahrain that al Qaeda is casing the U.S. border with Mexico to assess how to send terrorists and weapons into the United States ("Al Qaeda eyes," 2009). Al Nafisi stated,

"Four pounds of anthrax carried by a fighter through tunnels from Mexico into the U.S. are guaranteed to kill 330,000 Americans within a single hour if it is properly spread in population centers there," the recruiter said. "What a horrifying idea; $9 / 11$ will be small change in comparison. Am I right? There is no need for airplanes, conspiracies, timings and so on. One person, with the courage to carry four pounds of anthrax, will go to the White House lawn, and will spread this 'confetti' all over them, and then we'll do these cries of joy. It will turn into a real celebration (para. 5).

In addition, Hezbollah, an Iran-backed group based in Lebanon, is using routes that Mexican drug lords control to smuggle contraband and people into the United States to finance operations. According to one counterterrorism official, while Hezbollah appears to view the United States primarily as a venue to finance its operations elsewhere, "it should not be viewed lightly, as the money raised can be used against the U.S. or assets in future operations" ("Al Qaeda Eyes," 2009). According to Adolfo Aguilar Zinser, former Mexican national security adviser and ambassador to the United Nations, "in Northern Mexico, Islamic terrorist groups are using Mexico as a refuge ... In light of this situation, there are continuing investigations aimed at dismantling these groups so that they may not cause problems" ("Mexican and Canadian Drug Tunnels," 2010, para. 3).

\section{EGYPT}

Prior to 2012, the tunnels connecting the Gaza Strip and Egypt were not used by terrorist operations targeting Egypt. Thus, prior to 2012, Egypt's response to Gaza Strip smuggling tunnels was to seal off the tunnel (usually concrete) and assign a guard at the tunnel exit (in Egypt) for a period of time. In 2012, the Egyptian response to the Gaza Strip tunnels was a non-military response demonstrated by a country whose national security was not threatened. The Egyptian sealing-off of smuggling tunnels via flooding occurred in August 2012, two days after gunmen shot dead 16 Egyptian border guards in an attack blamed partly on Palestinian Islamists. During the attack, some 35 armed men believed to have come through a tunnel stormed an Egyptian military base, killing 16 police officers and soldiers. Egypt branded the attackers "infidels" and vowed to launch a crackdown throughout the Sinai. The Hamas government had condemned the attack as an "awful crime" and promised to help Egypt find the culprits, but also denied Gaza militants were involved. ("Egypt Moves to Seal Off Gaza," 2012, para. 2).

According to Akram and Kirkpatrick (2013), the Egyptian military began in February 2013, for the first time, to use wastewater to flood about two dozen of the 200-odd tunnels. Analysts speculated that there were a number of reasons for Egypt's recent attempts to control the Gaza Strip smuggling tunnels. The first reason theorized was to shut the tunnels to block the destabilizing flow of weapons and militants into Sinai from Gaza. Analysts offered many theories about the timing. At a moment of political and economic difficulties, with a financial aid package stalled in the United States Congress, Egypt's Islamist-led government "is showing itself once more as a valuable ally" (para. 6).

A political policy shift regarding Egyptian interventions to reduce or stop absolute contraband smuggling via Gaza Strip tunnels occurred in Egypt when military forces began work to seal off smuggling tunnels into the Gaza Strip using a procedure in which the tunnels were flooded. The shift in Egypt's response to the Gaza Strip tunnels is significant for a variety of reasons. There was a significant change in the manner in which the terrorist operatives elected to target the government. Specifically, Egyptian history is marked by terrorist operations targeting government officials. The 1981 assignations of Anwar Sadat and government facilities such as embassies by the Salafi Jihad 
movement is the basis of the social network studied by Sageman (2004). The 2012 terrorist operation was a direct assault on a border police station that included the killing of border officers. As such, the terrorist attack was not targeting military personnel nor was the attack targeting a military institution. Thus, there was a significant change in terrorist operatives electing to use the Gaza Strip tunnel system to launch a terrorist operation as opposed to using the tunnels to finance the terrorist organizations. The terrorists' use of the Gaza Strip tunnel another time to launch a terrorist operation against Egypt, with the same tunnel method used against Israel, is significant. Although it can be argued that the terrorists were still operating in the same area of the world-Gaza Strip-the fact that the same terrorist methods used against Israel were used against Egypt suggests that transnational social network analysis of terrorist groups' use of tunnels to launch terrorist attacks against Israel may have more in common with the social network analysis of Qin et al. (2005) and Sagemen (2004) than initially suspected.

In response to terrorist attacks on the border station and guards, Egypt elected to not to use a military response, such as a strike on terrorist command and control personnel or locations. Instead it escalated a non-lethal response-flooding the tunnels with water and raw sewage-thus contaminating the soil and complicating the tunnels' reconstruction process ("Egypt Moves to Seal Off Gaza," 2012). An alternative hypothesis was that Egypt's government aimed to remind Israel that Israel, not Egypt, still bore responsibility for Gaza's poverty and problems. Or perhaps the Egyptian military was sending some domestic message of its own, either to the Brotherhood or other domestic constituents, about the Egyptian generals' independence from the Islamists.

Regardless of the current political motivations of the politicians and the Egyptian government, it has been understood that Egypt could exercise significant control over both absolute and conditional contraband smuggling into and out of the Gaza Strip. The review of secret U.S. Embassy cables prior to the attack on the Egypt border guards revealed there was international recognition that Egypt played a pivotal role in addressing the smuggling tunnels of Gaza. In response to a query on Egyptian seriousness in stopping smuggling, Major General Harel stated that Egyptian support was split.

On the intelligence side, under Suleiman, cooperation was good. On the military side, however, Field Marshall Tantawi was dragging his feet' ('IDF Deputy Chief Of Staff ," 2009, para. 4). He also explained that the issue was more than just a technical issue, or an ideal number of Egyptian troops along the Philadelphi; it was more about willpower...fighting the problem from the last 1000 meters before the Philadelphi border is useless and we should instead address the source of weapons, which come from well-known routes beginning along the SudaneseEgyptian border. The majority of weapons smuggling comes from the Sudan border and makes its way by land across Egypt and into the Sinai. A small portion comes through Yemen, and some from Lebanon, but the Israeli sea blockade forces vessels to off-load in Egypt before goods can move towards Gaza. Once in the Sinai, there are only four major paved roads, and Egypt could easily interdict these routes with road blocks. Harel reiterated Egypt must close the border with Sudan, control the four roads in the Sinai, and change its Bedouin Policy (U.S. Embassy Tel Aviv, 2009b, para. 5).

Of interest in respect to the transnational analysis of tunnels used for smuggling absolute contraband and for terrorist operations was the social network analysis of the individuals and organizations involved in the assault on the Egyptian police station and border guards.

\section{CONCLUSION}

The similarities and differences between tunnels used for terrorist operations, terrorist and criminal organizations' use of smuggling tunnels to smuggle conditional contraband for profit, and terrorists' use of tunnels to smuggle absolute contraband cannot be determined by structural analysis of smuggling tunnels alone. Social network analysis of the individuals and groups involved in criminal and terrorist operations of tunnels is required. Social network analysis, which investigates the similarities and difference between the criminal and terrorist groups, is most likely to provide the required data to target individuals, groups, and tunnels involved in terrorist operations, as well as specific tunnels that threaten border security.

In the past ten years, there have been several key articles published regarding social network analysis of 
criminal enterprises, terrorist cells and several regarding terrorist organizations

It is essential that this social network model, developed to analyze individuals and groups involved in cross-border tunnel smuggling, exploit what has been learned by the analysis of social network models describing individual criminals and criminal organizations and terrorist cells and organizations. To achieve this goal, it must be understood that criminals and terrorists exploiting cross-border tunnels are interacting through shared social networks, links, and hubs. Thus, the work ahead is to develop a model that will analyze these connections. The authors opine that a longitudinal study be completed that gathers information on specific smugglers and smuggling organizations as they drop out or evolve through the different smuggling phases with specific attention to which smugglers and smuggling organizations serve as support for a terrorist operation cell or funding of a terrorist organization. A consideration is that, in some areas of the world, low technology social network data collection, based on methodologies similar to the village survey and snowball method, could be used in addition to other less technologically advanced methods, such as traffic analysis, prior to attempts to use social network models based on missing data bits required for more advanced computer-driven social network analysis models. Such a social network analysis will provide information necessary for a reasonable government policy ranging from nonlethal measures such as closing or flooding tunnels and pursuing criminal investigations, to military options such as military attacks on terrorists or cross-border smuggling organizations.

\section{REFERENCES}

Akano, O. (1986). The Effect of Smuggling on the Protection of Industries in Nigeria. Ibadan, Niser: Nigerian Institute of Social and Economic Research.

Akram, F. \& Kirkpatrick, D.D. (2013). To block Gaza tunnels, Egypt lets sewage flow. The New York Times. Retrieved from http://www.nytimes.com/2013/02/21/world/middleeast/egypts -floods-smuggling-tunnels-to-gaza-with-sewage.html

Al Qaeda eyes bio attack from Mexico. (2009). The Washington Times. Retrieved from http://www.washingtontimes.com/ news/2009/jun/03/al-qaeda-eyes-bio-attack-via-mexicoborder/ 9

Alster, P. (2013). The truth about Hamas' smuggling tunnels, IPT News, TribunePublié. Retrieved from http://www.crif.org/fr/ tribune/truth-about-hamas-smuggling-tunnels/35395

Attorneys General Reno and Madrazo sign letter to enhance cooperation. (1998 July 2). U.S. Department of Justice Press Release \#312: 07-02-98. Retrieved from: http://www.justice.gov/opa/pr/1998/July/312ag.html
Beittel, J.S. (2013). Mexico's drug trafficking organizations: Source and scope of the violence. United States Congressional Research Service. 7-5700, R41576. Retrieved from: www.crs.gov

Billingslea, W. (2004). Illicit cigarette trafficking and the funding of terrorism. Police Chief, 70(2), 49-54. NCJ 205099.

Caldwell, D., Ehlen, J.,\& Harmon, R. (2004). Studies in Military Geography and Geology New York: Kluwer Academic. http://dx.doi.org/10.1007/978-1-4020-3105-2

Carrington, P. J., Scott, J., \& Wasseman, S. (2005). Models and Methods in Social Network Analysis. Cambridge University Press. http://dx.doi.org/10.1017/CBO9780511811395

Chumley, C.K. (2013). France agrees to list Hezbollah as terrorist group. The Washington Times. Retrieved from http://www.washingtontimes.com/news/2013/mar/29/franceagrees-list-hezbollah-terrorist-group/

Coles, N. (2001). It's not what you know-it's who you know that counts: Analyzing serious crime groups as social networks. British Journal of Criminology, 41, pp.580 to 594. http://dx.doi.org/10.1093/bjc/41.4.580

Dayan, Y. (2012). Analysis: IDF aware Operation Pillar of Defense in Gaza not a long-term solution to Palestinian rocker fire on south. Ynetnews. Retrieved from http://www.ynetnews.com/ articles/0,7340,L-4312017,00.html

Egypt moves to seal off Gaza smuggling tunnels. (2012). The Jerusalem Post. Retrieved from http://www.jpost.com/Middle East/Article.aspx?id=280388/

Exum, A. (2006). Hizballah at war: A military assessment. The Washington Institute for Near East Policy, Policy Focus \#63. Retrieved from http://www.lebanonwire.com/0701MLN/ Hezbollah_at_war.pdf

Farquhar, S.C. (2011). Back to basics: A study of the second Lebanon war and operation CAST LEAD. Fort Leavenworth, KS: Combat Studies Institute Press.

Gaza tunnels being quickly rebuilt after Israel claimed to have successfully targeted smuggling network. (2012). CBSNews. Retrieved from http://www.cbsnews.com/8301-202_16257558663/gaza-tunnels-being-quickly-rebuilt-after-israelclaimed-to-have-successfully-targeted-smugglingnetwork.html/

Gazans move quickly to rebuild bombed tunnels to bring in food, weapons. (2012). NBC News. Retrieved from http://worldnews.nbcnews.com/_news/2012/11/26/15454998gazans-move-quickly-to-rebuild-bombed-tunnels-to-bring-infood-weapons/lite

Grillo, I. (2009). Autumn of the Capo: The diary of a drug lord. Time Online. Retrieved from: www.time.com/time/world/article/ $0,8599,1899404,00 . h t m l$

Hamas gunmen execute six 'Israeli spies' as Netanyahu hints at cease-fire. (2012). National Post. Retrieved from http://news.ntionalpost.com/2012/11/20/hamas-gunmenexecute-six-israeli-spies-on-busy-gaza-street-corner/

Heisman, M. and Snijders, T. (2003). Statistical analysis of longitudinal network data with changing composition. Sociological Methods and Research, 32: 253-87. http://dx.doi.org/10.1177/0049124103256096

Ilan, S. \& Haaretz Correspondent. (2008). In symbolic vote, Knesset okays MP's post-Winograd speech. Haaertz. Retrieved from: http://www.haaretz.com/hasen/spages/951073.html.)

Israel: Rockets fired from Gaza Strip. (2013). Retrieved from Stratfor Global Intelligence website at http://www.stratfor.com/ analysis/update-israel-gaza-conflict

Israel's military says explosive-filled tunnel explodes near soldiers on Israel-Gaza border. (2012). Fox News. Retrieved from http://www.foxnews.com/world/2012/11/08/israel-militarysays-explosive-filled-tunnel-explodes-near-soldiers-onisrael/\#ixzz2MQb34RqY 
Kalman, M. (2012). Hamas victim dragged through streets of Gaza City. New York Daily News. Retrieved from http://www.nydailynews.com/.../hamas-victim-draggedstreets-collaborator-widow-article-1.1208004/

Karthika, S. \& Bose, S. (2011a). Analyzing various social networking approaches for covert networks. Trends in Network and Communications, Communications in Computer and Information Science, 197, 558-566. http://dx.doi.org/10.1007/978-3-642-22543-7 57

Karthika, S. \& Bose, S. (2011b). A comparative study of social networking approaches in identifying the covert nodes. International Journal on Web Services Computing (IJWSC), 2, 65-78.

http://dx.doi.org/10.5121/ijwsc.2011.2306

Katz, Y. \& Hendel, Y. (2012). Israel vs. Iran: The shadow war. Washington, D.C.: Potomac Books.

Kempster, N. (1998). U.S., Mexico Vow Better Communication Diplomacy: In wake of furor over Operation Casablanca, nations pledge to inform each other about sensitive activities. Los Angeles Times Online. Retrieved from: http://articles.latimes.com/1998/jul/03/news/mn-477

Killebrew, R. (2011). Not just about Mexico; not just about drugs. In The Hybrid Threat: Crime, Terrorism and Insurgency in Mexico. Proceedings of the Joint Policy and Research Forum, A Joint CSL-HSPI Study, Retrieved from http://www.csl.army.mil/usacsl/publications/HybridThreatMon ographInternetVersion.pdf

Krebs, V. (2001). Mapping networks of terrorist cells. Connections, 24, 43-52.

Lichtenwald, T.G. (2003). Drug smuggling behavior: A developmental smuggling model (Part 1). Forensic Examiner. National Criminal Justice Reference \#NCJ209084 http://www.allabout-psychology.com/support-files/drug_smuggling_part_1. pdf

Lichtenwald, T.G. (2004). Drug smuggling behavior: A developmental smuggling model (Part 2). Forensic Examiner, National Criminal Justice Reference Service \#NCJ209085. http://www.all-about-psychology.com/supportfiles/drug_smuggling_part_2.pdf

Lichtenwald, T.G., Perri, F.S., \& MacKenzie, P.M. (2009). Smuggling multi-consignment contraband: Isolated incidence or a new trend? Inside Homeland Security, 7(2), NCJ \# 227306 http://www.all-about-forensic-science.com/supportfiles/smuggling.pdf

Lichtenwald, T.G. \& Perri, F. S. (2011). Smuggling tunnels: The need for a transnational analysis. Inside Homeland Security, 9(1), NCJ Number 23418. http://www.all-about-forensicscience.com/support-files/tunnels.pdf

Lintner, B. (2009). 'Tunnels, guns and Kimchi: North Korea's quest for dollars - Part l'. Yale Global. Retrieved from http://yaleglobal.yale.edu/content/NK-quest-for-dollars-part1

Mam, A. E., Kinney, J. B.,\& Pollard, N.R. (2008). Social network and distance correlates of criminal associates involved in illicit drug production. Security Journal, 21, 77-94. http://dx.doi.org/10.1057/palgrave.sj.8350069

Marosi, R. (2011). Controversial Muslim cleric is arrested while sneaking into the U.S. Los Angeles Times. Retrieved from: http://articles.latimes.com/2011/jan/27/local/la-me-bordercleric-20110127

McGloin, J. M. \& Kirk, D. S. (2010). An overview of social network analysis. Journal of Criminal Justice Education, 2, 169-181. http://dx.doi.org/10.1080/10511251003693694

Mexico: Open access to U.S. security agencies ends. (2013). Retrieved from Stratfor Global Intelligence website at http://www.statfor.com/situation-report/mexico-open-acessus-security-agencies-ends

Mexico security memo: Prevalent propaganda and promises to fight crime (2013 March 27). Retrieved from Stratford Global
Intelligence website at http://www.stratfor.com/topics/ terrorism-and-security/tracking-mexicos-drug-cartels

Mexican and Canadian Drug Tunnels. (2010). Retrieved from http://www.terroristplanet.com/2010/02/mexican-andcanadian-drug-tunnels/

Miller, G. (2010). CIA acts on fear of al-Qaeda plot to hit in Europe. Washington Post. Retrieved from:http://www.washingtonpost. com/wpdyn/content/article/2010/09/28/AR2010092806935_pf .html

Mohamad Youssef Hammoud sentenced to 30 years in terrorism financing case. (2011). Retrieved from http://www.ice.gov/ news/releases/1101/110127charlotte.htm

Mora, E. (2010). Justice Department reports 60 percent increase in number of drug smuggling tunnels at U.S.-Mexican border. Retrieved from: http://www.cnsnews.com/node/64442

Morsell, C. (2009). Inside criminal networks, studies of organized crime. Springer Social Sciences-Criminology and Criminal Justice, 8, ISBN 978-0-387-09526-4.

Morin, M. (2007). Afghan tunnels prove tough to crack. Stars and Stripes. Retrieved from: http://www.afghanistannewscenter. com/news/2007/july/jul192007.html

Norton-Taylor, R. \& Bowcot, O. (2010). Mumbai-style' terror attack on UK, France and Germany foiled, Drone attacks intercept militants based in Pakistan Western intelligence agencies confirm plot fears. Retrieved from http://www.guardian.co.uk world/2010/sep/29/terror-attack-plot-europe-foiled

Oladeji, K. (2010). Psychosocial Predictors of Smuggling Behaviour among Suspected Smugglers in Selected Border Areas in Nigeria. MMP Thesis, Unpublished. Ibadan: University of Ibadan.

Oladeji, M.O. (2010). Perception of smuggling among the Yoruba people of Oke-Ogun of South Western Nigeria. Internet Journal of Criminology, 1-13.

Olapegba, P.O. \& Idemudia, E.S. (2012). Dispositional and contextual factors predicting smuggling behaviour among smugglers in border areas in Nigeria. Journal of Psychology, 3(2): 59-64. Retrieved from http://www.krepublishers.com/02Journals/JP/JP-03-0-000-12-Web/JP-03-2-000-12-AbstPDF/JP-03-2-059-12-086-Olapegba-P-O/JP-03-2-059-12086-Olapegba-P-O-Tt.pdf

Perri, F.S., Lichtenwald, T.G., \& MacKenzie, P.M. (2009). Evil Twins: The Crime-Terror Nexus, Forensic Examiner, 18(4), 16-29. http://www.all-about-psychology.com/support-files/crimeterror-nexus.pdf

Qin, J., Xu, J.J., Hu, D., Sageman, M., \& Chen, H. (2005). Analyzing terrorist networks: A case study of the Global Salafi Jihad network. IEEE International Conference on Intelligence and Security Informatics, ISI 2005, Atlanta, GA, USA, May 19-20, 2005. Proceedings.

Pantucci, R. (2013). France confronts terror threat in Africa, risks attack at home. RUSI Royal United Services Institute Analysis. Retrieved from http://www.rusi.org/analysis/ commentary/ref:C50F7C5DB4E4D6/

Papachristos, A. V. (2011). The coming of a networked criminology. In J. MacDonald (ED.), Measuring crime and criminality (pp. 101-140). New Brunswick, N.J.: Transaction Publishers.

Ressler, S. (2006). Social network analysis as an approach to combat terrorism: Past, present, and future research. Homeland Security Affairs, 2. Retrieved from http://www.hsaj.org

Roggio, W. \& Lundquist, L. (2010). European terror plot begins to unravel. Retrieved from: http://www.longwarjournal.org/ archives/2010/09/european_terror_plot.php\#ixzz2P9u72zHe

Rudoren, J. \& Akram, F. (2012). Suspected collaborator with Israel killed on Gaza street. The New York Times. Retrieved from http://nytimes.com/2012/11/17/world/middleeast/suspectcollaborator-with-israel-executed-in-gaz.html 
Russell, G. (2001). Mexico slowdown on the border. Time Magazine Online. Retrieved from: http://www.time.com/time/magazine/ article/0,9171,141219,00.html

Sageman, M. (2004). Understanding Terror Networks. Philadelphia: University of Pennsylvania Press

Schiff, Z. (2006). Kidnap soldiers in July was Hezbollah's fifth attempt Israel told diplomats after learning of previous plans it would respond with military operations to kidnap attempts. Retrieved from: http://www.haaretz.com/news/kidnap-ofsoldiers-in-july-was-hezbollah-s-fifth-attempt-1.197595

Shelley, L, (n.d.). The nexus of organized international criminals and terrorism. Retrieved from: http://pagespersoorange.fr/ societe.internationalede.criminologie/pdf/Intervention\%20She lley.pdf.

Shelley, J., Picarelli, A.I., Hart, D.M., Craig-Hart, P.A., Williams, P., Simon, S., \& Covill, L. (2005). Methods and motives: Exploring links between transnational organized crime and international terrorism. Retrieved from http://www.ncjrs.gov/ pdffiles1/nij/grants/211207.pdf -

Slovakia's borders: Tunnel vision. (2012, July 24). [Web log post]. Retrieved from http://www.economist.com/blogs/ easternapproaches/2012/07/slovakias-borders/

Smuggling tunnel to Hong Kong uncovered. (2006). Space Daily. Retrieved from: http://www.spacedaily.com/reports/ Smuggling_Tunnel_To_Hong_Kong_Uncovered_999.html

Snijders, T. A. B. (2001). The statistical evaluation of social network dynamics. Sociological Methods, 31, 361-95. http://dx.doi.org/10.1111/0081-1750.00099

Spagat, E. (2010). San Diego drug tunnel had railcar, tons of pot. Associated Press. Retrieved from http://www.wtopnews.com/ ?nid=104\&sid=2104884

Startex. (2011, February 18). Last American Agent Killed in Mexico, Kiki Camarena. [Web Blog]. Retrieved from: http://www.officialcoldcaseinvestigations.com/showthread.ph $\mathrm{p} ? \mathrm{t}=13846$

Stewart, S. \& Reed, T. (2013 March 28). Mexico: The 'new narcoreality' is already here. Stratfor Global Intelligence. Retrieved from http://www.stratfor.com/weekly/mexico-new-narcoreality-already-here

Summary of Operation Pillar of Defense (2012). Retrieved from http://www.israelpolitik.org/2012/11/21/summary-ofoperation-pillar-of-defense/
The fight against terrorism in the European Union. (2010).Retrieved from http://www.diplomatie.gouv.fr/en/french-foreign-policy1/defence-security/terrorism/the-fight-against-terrorism-inthe/

The Gaza War. (2013). Retrieved from Wikipedia http://en.wikipedia.org/wiki/Gaza_War/ground-forces-entergaza-to-find-explosives-planted-along-border/

The Hybrid Threat: Crime, terrorism and insurgency in Mexico. (2012). Proceedings of the Joint Policy and Research Forum: A Joint CSL-HSPI Study. Retrieved from: http://www.csl.army.mil/usacsl/publications/HybridThreatMon ographlnternetVersion.pdf

Toameh, K.A. (2012). "How many millionaires live in the "impoverished" Gaza Strip?" Retrieved from http://www.gatestoneinstitute.org/3308/gaza-millionaires)

Topol, S.A. (2013). Twilight of Gaza's smuggling tunnel millionaires. Retrieved from http://www.businessweek.com/articles/201301-31/twilight-of-gazas-smuggling-tunnel-millionaires

United States One Hundred Twelfth Congress $-2^{\text {nd }}$ session. (3 January 2012). Border Tunnel Prevention Act of 2012 H.R.4119, Retrieved from http://www.govtrack.us/ congress/bills/112/hr4119/text

United States of America v. Manssor Arbabsiar and Gholam Shakuri. (2011). Retrieved from: http://www.justice.gov/opa documents/us-v-arbabsiar-shakuri-complaint.pdf

U.S. citizen with al Qaeda links arrested in Spain. (2010). Retrieved from http://www.reuters.com/article/2010/09/29/us-spainalqaeda-idUSTRE68S1XQ20100929

U.S. Embassy Tel Aviv. (2009a, Feb. 9). Senior U.S. and Israeli officials discuss efforts to combat arms smuggling. Retrieved from http://wikileaks.org/cable/2009/02/09TELAVIV420.html

U.S. Embassy Tel Aviv. (2009b, Feb. 19). [cable]. IDF Deputy Chief of Staff discusses Gaza Operation Cast Lead and U.S. Egyptian roles to slow smuggling to Hamas Embassy. Retrieved from http://wikileaks.org/cable/2009/02/ 09TELAVIV422.html aka Wikileaks id \#192857

Welch, W. (2006). In age of terror, US fears tunnels pose bigger threat. USA Today. Retrieved from: http://www.usatoday. com/news/nation/2006-03-01-tunnel-terror x.htm

Zion, I.B. (2012). IDF ground forces briefly enter Gaza after finding tunnel packed with explosives. The Times of Israel. Retrieved from http://www.timesofisrael.com/idf-

Received on 29-04-2013

Accepted on 10-06-2013

Published on 17-06-2013

DOI: http://dx.doi.org/10.6000/1929-4409.2013.02.21

(C) 2013 Lichtenwald and Perri; Licensee Lifescience Global.

This is an open access article licensed under the terms of the Creative Commons Attribution Non-Commercial License (http://creativecommons.org/licenses/by-nc/3.0/) which permits unrestricted, non-commercial use, distribution and reproduction in any medium, provided the work is properly cited. 